\title{
ART THERAPY UNTUK MENINGKATKAN KONTROL DIRI PADA ANAK DIDIK LAPAS
}

\author{
Ika Amalia Kusumawardhani ${ }^{1}$, Woro Kurnianingrum ${ }^{2}$, dan Naomi Soetikno ${ }^{3}$ \\ ${ }^{1}$ Fakultas Psikologi, Universitas Tarumanagara Jakarta \\ Email:ikusuamalia@gmail.com \\ ${ }^{2}$ Fakultas Psikologi, Universitas Tarumanagara Jakarta \\ Email: woro.kurnianingrum@gmail.com \\ ${ }^{3}$ Fakultas Psikologi, Universitas Tarumanagara Jakarta \\ Email: naomis@fpsi.untar.ac.id
}

\begin{abstract}
ABSTRAK
Perubahan dramatis yang berkaitan dengan emosi, penilaian, perilaku, dan kontrol diri, cenderung menjadi penjelasan seorang remaja mengalami ledakan emosi dan melakukan kegiatan berisiko (Papalia, Olds, \& Feldman, 2009). Perbuatan beresiko tersebut salah satunya adalah perbuatan yang melibatkan hukum. Tujuan dari penelitian ini adalah untuk menerapakan art therapy dalam mengingkatkan kontrol diri pada andikpas (anak didik lapas) yang dilaporkan melakukan pelangaran di dalam instansi. Pelanggaran di dalam instansi lapas yang dilakukan oleh andikpas dapat berupa perkelahian, merokok, tidak bersekolah dan tidak mengikuti kegiatan pembinaan. Metode penelitian yang dilakukan adalah quasi eksperimental dengan jumlah partisipan 5 orang yang dilaporkan pernah hingga sering memasuki sel isolasi karena melakukan pelanggaran. Prosedur pemilihan partisipan diawali dengan melakukan pre-test menggunakan tes menggambar orang, menggambar pohon, dan kuesioner brief self-control scale milik Tangney et al (2004) berjumlah 13 butir item. Didapatkan 5 orang yang memiliki karakteristik kontrol diri yang rendah. Art therapy dilakukan sebanyak 8 kali pertemuan dalam 1 bulan. Hasil yang diperoleh melalui penerapan art therapy adalah, adanya peningkatan kontrol diri dilihat dari post test yang mencakup observasi dan penilaian perbedaan respon aitem dari partisipan pada saat pre-test dan post-test. Kontrol diri yang meningkat pada partisipan berkaitan dengan sikap pemalas, pengendalian diri, dan regulasi emosi.
\end{abstract}

Kata kunci: kontrol diri, art therapy, lembaga permasyrakatan, lembaga pembinaan khusus anak, pelanggaran, anak didik lembaga permasyarakatan.

\section{PENDAHULUAN \\ Latar Belakang}

Remaja merupakan masa-masa labil dikarenakan masa ini merupakan masa peralihan dari masa kanak-kanak menuju masa dewasa. Masa Remaja merupakan periode peralihan masa perkembangan, terbentang antara usia 11 sampai sekitar 20 tahun (Papalia, Olds, \& Feldman, 2009) atau usia 10 hingga 12 tahun sampai 18 hingga 21 tahun (Santrock, 2011). Perubahan dramatis yang berkaitan dengan emosi, penilaian, perilaku, dan kontrol diri berlangsung antara masa pubertas dan dewasa awal, serta menjadi penjelasan kencenderungan remaja mengalami ledakan emosi dan melakukan kegiatan berisiko (Papalia, Olds, \& Feldman, 2009). Perbuatan beresiko tersebut salah satunya adalah perbuatan yang melibatkan hukum.

Keterlibatan anak dengan hukum dapat berupa berbagai macam hal seperti tindak kekerasan, pencurian, penyalahgunaan obat-obatan terlarang, dan tindakan lainnya yang diatur dalam perudang-undangan merupakan perilaku yang dapat dijatuhi sanksi hukum. Dalam peraturan perundang-undangan Indonesia, disebutkan dalam Undang-Undang No. 35 tahun 2014 tentang perlindungan anak pasal No. 59 ayat 2 bagian b, " perlindungan khusus diberikan untuk anak yang berhadapan dengan hukum". Lebih lanjut bentuk dari perlindungan tersebut dijelaskan pada pasal 64 berupa; perlakuan secara manusiawi dengan mempertimbangkan kebutuhan sesuai dengan umurnya, pemberian bantuan hukum, pemberlakuan kegiatan rekreasional, pemberian pendidikan, dan pemberian hak lain yang diatur dalam perundang-undangan (KPAI, 2017). Dalam artikel ini dilaporkan bagaimana penerapan art therapy untuk meningkatkan kontrol diri 
pada anak didik lapas yang melakukan pelanggaran di LPKA (lembaga pembinaan khusus anak) kemudian hingga mendapatkan sangsi untuk masuk ke sel isolasi.

\section{Anak didik lapas}

Undang-undang No. 11 tahun 2012 tentang sistem peradilan anak pasal 1 No. 20 menyebutkan bahwa lembaga pembinaan khusus anak yang selanjutnya disebut sebagai LPKA adalah lembaga atau tempat anak menjalani masa hukuman. Seperti yang telah disebutkan dalam perudangundangan tempat anak mendapatkan pembinaan merupakan lembaga pembinaan khusus anak atau biasa disebut LPKA. Sedangkan anak yang sedang dibina dalam lembaga biasa disebut dengan anak didikan lembaga permasyarakatan atau Andikpas (anak didik lapas). Lebih lanjut dalam pasal tersebut dijelaskan bahwa andikpas merupakan anak pidana berdasarkan putusan pengadilan untuk menjalani pidana paling lama hingga berusia 18 tahun, anak Negara berdasarkan putusan pengadilan diserahkan oleh Negara untuk dididik paling lama hingga berusia 18 tahun, anak sipil yang atas permintaan orang tua atau wali memperoleh penetapan pengadilan untuk dididik di lapas paling lama hingga berusia 18 tahun. Anak didik lapas juga wajib didaftarkan seperti narapidana lainya dengan maksud yang sama dan sistem dan mengubah status dengan tata cara yang sama dengan narapidana.

\section{Anak didik lapas yang memasuki sel isolasi}

Dari hasil wawancara mengenai anak didik lapas yang sulit diarahkan dalam instansi, anak yang memiliki pendidikan rendah, yaitu paket A dan B lebih banyak yang sulit untuk diarahkan untuk mengikuti pembinaan dalam instansi. Sedangkan andikpas yang memiliki pendidikan kejar paket $\mathrm{C}$ sedikit yang sulit untuk diarahkan. Bobot kegiatan dalam lembaga tergolong sedang tidak terlalu tinggi. Untuk anak dengan kejar paket A dan B memiliki waktu belajar yang lebih singkat dibandingkan anak didik lapas dengan program kejar paket C. Kegiatan lain yang adakan oleh pihak luar lembaga bekerja sama dengan LPKA, tidak diberikan kepada semua anak. Dalam hasil wawancara dengan petugas dan tamping yang telah di berikan kewenangn, kegiatan pembinaan yang melibatkan pihak luar biasanya dberikan pada anak yang lebih mudah diarahkan. Lewat hasil wawancara tersebut dapat disimpulkan bahwa anak yang kurang dapat diarahkan menjadi tidak memiliki kesempatan untuk mendapatkan kegiatan pembinaan yang beragam.

Sulit diarahkan yang dimaksud adalah kegiatan melakukan pelanggaran aturan dalam lapas hingga anak (remaja) mendapatkan saksi berupa memasuki sel khusus yaitu sel isolasi, dengan cara membantah petugas atau pendamping dalam tahanan dan membolos pada saat jadwal kegiatan. Sel isolasi atau yang biasa disebut dalam lembaga sebagai sel tikus (seltik) merupakan tempat dimana petugas memberikan tindakan terakhir untuk pembinaan anak yang masih melanggar peraturan setelah beberapa kali diberikan peringatan untuk; tidak merokok, tidak menggunakan uang di dalam lembaga, tidak mengunakan barang elektronik seperti telepon genggam, dan tidak berkelahi baik dengan sesama anak binaan maupun tahanan pendamping yang merupakan wakil petugas di dalam sel.

\section{Kontrol diri dan Art therapy}

Kontrol diri merupakan kemampuan individu untuk menyesuaikan tingkah laku dengan apa yang dianggap diterima secara sosial oleh masyarakat. Menurut Tangney, Baumeister dan Boone (2004) kontrol diri (self-control) merupakan kemampuan seseorang untuk melampaui atau merubah respon dalam diri juga untuk menghalangi perilaku yang tidak diinginkan muncul sebagai bentuk respon dari sebuah situasi. Lebih lanjut Tangney et al menjelaskan bahwa karakteristik kontrol diri adalah dapat mengendalikan pikiran, emosi, dorongan, dan mengatur 
performa serta dapat mengentikan kebiasaan. Blackhart (2011) menyatakan kontrol diri adalah kemampuan untuk mengendalikan dan meregulasi impuls atau dorongan, emosi, keinginan, harapan, dan perilaku lain yang berada di dalam diri. Tingkatan kontrol diri seseorang selalu dikaitkan dengan prestasi yang bagus dan kualitas kehidupan yang baik. Hal ini juga disebutkan oleh Hoffman dan Friese (2009) bahwa kontrol diri yang baik dihubungkan dengan sejumlah penurunan tinggkat agrsifitas dan kriminalitas, penyesuaian psikologis yang lebih baik, kesehatan mental, kemampuan akademik, hubungan peribadi, masalah keuangan yang lebih sedikit dan masalah pengaturan impuls seperti konsumsi rokok, alkohol, dan obat-obatan terlarang.

Kemampuan diri untuk mengendalikan dan mengatur diri sendiri dalam sebuah situasi bukanlah hal yang terjadi secara spontan dan tanpa usaha (Necka, 2015). Orang akan memperlihatkan kontrol diri ketika mereka harus mengikuti peraturan atau menghambat keinginan yang segera dirasakan untuk mulai bertindak (Baumeister \& Muraven, 2000). Pada kenyataanya di LPKA, sering kali terjadi pelanggaran-pelanggaran yang terlihat seperti tidak ada kontrol diri disertai adanya perilaku impulsif.

Kontrol diri dapat menurun saat lingkungan menolak apa yang dilakukan individu atau tidak menerima keberadaan individu (Blackhart, Nelson, Winter \& Rockney, 2011). Dalam kasus andikpas di dalam lembaga, lingkungan cenderung memberikan gambaran buruk terhadap anak yang memiliki masalah hukum. Penelitian ini ingin melihat pengaruh intervensi tertentu dalam meningkatkan kontrol diri, seperti yang telah disebutkan bahwa kontrol diri terjadi tidak secara spontan melainkan melalui sebuah proses yang membutuhkan usaha. Dengan mengendalikan diri individu dapat mencegah agresivitas yang dilakukan terhadap orang lain maupun orang terdekat (DeWall, Finkel \& Denson, 2011).

Salah satu intervensi yang digunakan dalam membantu anak didik lapas adalah art therapy. Menurut Rubin (2005), art therapy merupakan cara untuk memahami dan membantu orang lain dengan proses terapi melalui seni. Art therapy adalah bentuk psikoterapi yang menggunakan media seni, material seni dengan pembuatan karya seni untuk berkomunikasi. Media seni yang digunakan dapat berupa pensil, kapur berwarna, pensil warna, cat, potongan kertas, krayon, dan clay (Hallowell, 2007). Media atau aktivitas seni visual yang dapat digunakan antara lain menggambar atau melukis, membuat kolase, mengkonstruksi dengan tanah liat menjadi berbagai macam bentuk (Geldard dalam Mahardika, 2017).

Menurut Malchiodi (2003), proses pelaksanaan art therapy juga dapat menjadi sarana anak melepaskan emosi dan mengatasinya. Bentuk kegiatan dan media yang digunakan akan disesuaikan dengan kebutuhan klien dan tujuan terapi, yakni mengambar dengan kertas A3, kertas A4, dan pensil warna. Pada intervensi dalam penelitian ini, bentuk dari art therapy yang diberikan bertujuan untuk ekspresi diri anak dan bagaimana anak menghadapi aturan serta perubahan. Selain menggunakan aktifitas menggambar, peneliti juga menggunakan aktifitas konstruksi dan kolase pada media yang terbatas. Aktifitas ini bertujuan untuk membuat aturan dan melihat bagaimana anak menyesuaikan diri dengan mengontrol diri sendiri untuk mengikuti aturan tersebut. Aktivitas kegiatan akan dibuat berdasarkan tema yang disesuaikan dengan tahapan intervensi. Contoh kegiatan yang akan dilakukan, yaitu menggambar peristiwa yang tidak menyenangkan bagi Subyek, memvisualisasikan perasaan marah ke dalam sebuah objek dengan menggunakan gambar. Dalam penelitian Koiv dan Kaudne (2015) menyebutkan bahwa terapi seni (art therapy) yang dilakukan sebanyak dua kali seminggu selama lima minggu menunjukan penurunan pada tingkat agresifitas yang ditunjukan oleh partisipan lewat kendali diri dan lebih tenang dalam meregulasi diri.

Menurut Taghva dan Nezhadi (2010), dengan mengunakan terapi seni yaitu teknik yang dijadikan jembatan/alat bantu untuk anak-anak menunjukkan perasaan mereka dan pikiran mereka khususnya perasaan marah, balas dendam, dan agresivitas, dapat di disain sesuai dengan 
kebutuhan anak-anak. Peningkatan kontrol diri menjadi penting agar anak didik lapas dapat menaati peraturan yang dibuat untuk membantu jalannya program pembinaan. Dalam penelitian Gunawan (2017) menunjukan bahwa semakin tinggi tingkat pengendalian diri maka individu akan memiliki kedisiplinan tinggi yang ditunjukan melalui mematuhi peraturan dan menaati norma. alam pembahasan kali ini yang berhubungan dengan remaja dan kontrol diri. Bentukbentuk kegiatan yang dilakukan dalam terapi diharapkan dapat menurunkan kecenderungan remaja melakukan tindakan impulsif, agar dapat menampilkan perilaku yang lebih positif dalam kehidupan sehari-hari. Bentuk dari intervensi yang digunakan juga merupakan intervensi kelompok yang diharapkan lewat setting tersebut setiap partisipan dapat belajar dan memperoleh kontrol diri dari hubungan dan penerimaan kelompok terhadap diri.

\section{Rumusan Masalah}

Apakah intervensi art therapy dapat meningkatkan kontrol diri anak didik lapas yang sering melakukan pelanggaran hingga memasuki sel isolasi ?

\section{METODE PENELITIAN}

Partisipan penelitian partisipan merupakan anak didikan lapas (andikpas) yang dikeluhkan sering atau perah memasuki sel isolasi. Partisipan berjumlah 15 orang remaja laki-laki dengan keluhan serupa yaitu sering memasuki sel isolasi. Prosedur penelitian diawali dengan memberikan pre tes pada 15 orang andikpas. Dari 15 orang remaja yang melalui proses screening menggambar manusia dan menggambar pohon. Kemudian diperoleh 5 orang remaja laki-laki dengan latar belakang kasus pidana yang berbeda-beda, dan akan melakukan kegiatan art therapy.

Disain penelitian. Penelitian ini menggunakan disain penelitian quantitative one group pre-test and post-test serta menggunakan alat ukur brief self-control scale untuk melihat perbandingan sebelum dan setelah intervensi.

Lokasi penelitian. Penelitian ini dilakukan di dalam lembaga pembinaan khusus anak (LPKA) Salemba. Lembaga ditujukan untuk anak sipil, Negara maupun anak pidana yang telah maupun sedang menunggu putusan pengadilan. Penelitian dilaksanakan pada jam operasional lembaga yaitu senin-jumat, pada pukul 09.00 - 11.00 WIB dan 13.00-15.00 WIB. Penelitian dilaksanakan selama satu setengah bulan, berawal dari pengumpulan data dengan kuesioner kemudian intervensi.

Instrument penelitian. Instrument utama yang digunakan adalah asesmen menggambar manusia yang memiliki inter-rater reliabilitas .90 (Rae \& Hayland dalam Ozer, 2010). Penelitian ini juga menggunakan antara lain lembar surat izin untuk mengadakan penelitian dalam lembaga serta inform consent, alat ukur Brief Self-Control scale yang dikembangkan oleh Tangney dkk (2004), kertas A4 70gr, dan pensil HB. Peralatan tersebut digunakan untuk proses seleksi partisipan yang akan diberikan intervensi berupa kegiatan seni. Peralatan yang digunakan pada saat intervensi antara lain kertas gambar A3 50 lembar, alat tulis, kuas, cat poster, wadah cat, air, majalah bekas, lem kertas, kertas post-it, gunting (dalam pengawasan petugas), tanah liat instan, karton untuk membuat kotak, batu hiasan, rumput hiasan dan penggaris. 
Pengukuran. Penelitian ini menggunakan alat ukur Brief Self-Control Scale yang dikembangkan oleh Tangney, Baumeister, dan Boone (2004). Brief Self-Control Scale ini merupakan versi singkat dengan jumlah aitem sebanyak 13 pernyataan. Respon yang diberikan berupa ranking dari 1-5 dimana 1 merupakan respon tidak menggambarkan sama sekali, 3 merupakan respon rata-rata atau kadang-kadang, dan 5 merupakan respon sangat menggambarkan sekali. Brief SelfControl Scale berupakan alat ukur yang mengukur kemampuan untuk mengendalikan dan meregulasi impuls atau dorongan, emosi, keinginan, harapan, dan perilaku lain. Contoh dari salah satu aitem pada alat ukur ini adalah "saya merupakan seorang pemalas", "saya menolak hal yang buruk bagi saya", dan "saya sering kali bertindak tanpa memikirkan kemungkinan lain".

Pelaksanaan Intervensi Partisipan menjalani kegiatan art therapy selama delapan sesi pertemuan dalam satu bulan, yang dilakukan dua kali dalam seminggu. Art therapy yang diberikan mencakup pemberian tugas gambar bebas, menggambar potret diri, membuat hewan dari clay, menempel kolase, dan menggambar menggunakan cat. Setelah sesi art therapy selesai, partisipan mengerjakan menggambar manusia dan menggambar pohon serta mengisi brief selfcontrol scale. Setiap sesi pertemuan bertujuan untuk mengendalikan individu lewat kegiatan berkelompok.

\section{HASIL DAN PEMBAHASAN}

Dari kegiatan yang telah dilakukan untuk melihat penerapan art therapy dalam meningkatan kontrol diri pada 5 partisipan yang memiliki masalah kontrol diri, dapat disimpulkan bahwa art therapy dapat meningkatkan kontrol diri. Hal ini ditunjukan lewat perubahan pada tes mengambar manusia dan menggambar pohon yang terlihat lebih terarah. Selain itu terlihat dalam tes bahwa intervensi juga meningkatkan kepercayaan diri para partisipan. Pengukuran menggunakan kuesioner brief self-control scale (Tangney, 2004) terlihat adanya perubahan respon yang diberikan masing-masing partisipan. Pada grafik 1 terlihat bahwa terdapat empat orang partisipan yang memperlihatkan peningkatan skor pada saat post-test. Partisipan memiliki skor yang lebih tinggi pada saat pre-test dibandingkan pada saat post-test berjumlah satu orang.

Lebih lanjut nilai pada pre-test kurang sesuai dengan karakteristik kontrol diri yang rendah dilihat dari skala Tangney (2004) hal ini kurang sesuai dibandingkan tes menggambar manusia dan tes menggambar pohon (DAP dan Baum), dengan demikian dapat disimpulkan setelah partisipan mengetahui karakteristik dari peserta yang mengikuti kegiatan, partisipan berusaha untuk terlihat baik (faking good). Lebih lanjut intervensi yang diberikan kepada 5 partisipan menunjukan peningkatan kepercayaan diri, pengenalan diri, dan menumbuhkan kesadaran akan pengendalian diri untuk mencapai suatu tujuan.

Dalam analisa aitem alat ukur yang digunakan lebih dalam kepada para partisipan, terlihat beberapa perbahan skor aitem seperti dalam aspek sikap pemalas, pengendalian diri dan regulasi emosi. Partisipan 1 memiliki perubahan skor pada aspek sikap kerja, pengendalian diri dan regulasi emosi, partisipan 2 memiliki perubahan skor pada aspek sikap kerja, regulasi emosi dan sikap disiplin, partisipan 3 memiliki perubahan skor pada aspek pengendalian diri dan sikap kerja, partisipan 5 memiliki perubahan skor pada aspek pengendalian diri, regulasi emosi, dan sikap kerja. Sedangkan partisipan 4 yang menunjukan penurunan nilai menunjukan perubahan skor pada aspek sikap kerja dan regulasi emosi.

Kelebihan dari penerapan art therapy hingga kemudian dapat meningkatkan kontrol diri anak didik lapas LPKA salemba adalah kegiatan berkelompok yang mampu mengekspresikan emosi yang dirasakan. Aktivitas seni dapat mengurangi keinginan berlebihan yang dengan melakukan kegiatan yang melibatkan indera, emosi, dan kognisi dalam kegiatan interaktif yang memicu kreativitas atau pemecahan masalah dan membuat sesuatu yang tidak disadari menjadi disadari 
dengan pendekatan yang tidak mengancam (Huss, 2010). Hal ini ditunjukan para partisipan dengan hasil post-test yang memperlihatkan bahwa partisipan mengembangkan pengenalan diri sendiri dan menjadi lebih percaya diri. Selain itu pendekatan terapi kelompok memberikan dampak kontrol diri secara sosial yang dirasakan oleh partisipan. Terapi seni (art therapy) terbukti menurunkan rasa marah, membantu untuk membangun hubungan positif antar individu dimana mereka belajar bertoleransi dan bekerjasama dengan orang lain (Smeijsters et al, 2010).

Kekurangan dari penelitian ini adalah kurangnya data kuantitatif yang mendukung yaitu penggunaan kuesioner brief self-control yang digunakan sebagai data pendukung. Kurangnya pengarahan peneliti mengenai aitem-aitem yang disajikan oleh partisipan membuat partisipan mengungkapkan kesulitan untuk memberikan respon yang diinginkan. Di sisi lain partisipan yang memahami maksud dari diberikannya kuesioner memberikan respon yang tidak sesuai dengan hasil penilaian tes menggambar. Selain itu meskipun terbukti bahwa penerapan art therapy dapat meningkatkan kontrol diri, hasil yang diharapkan kurang maksimal. Temuan lain dalam wawancara akhir dengan para partisipan diketahui bahwa sebagian besar partisipan menikmati proses kreatif, mengendalikan diri dan bekerjasama dalam kelompok.

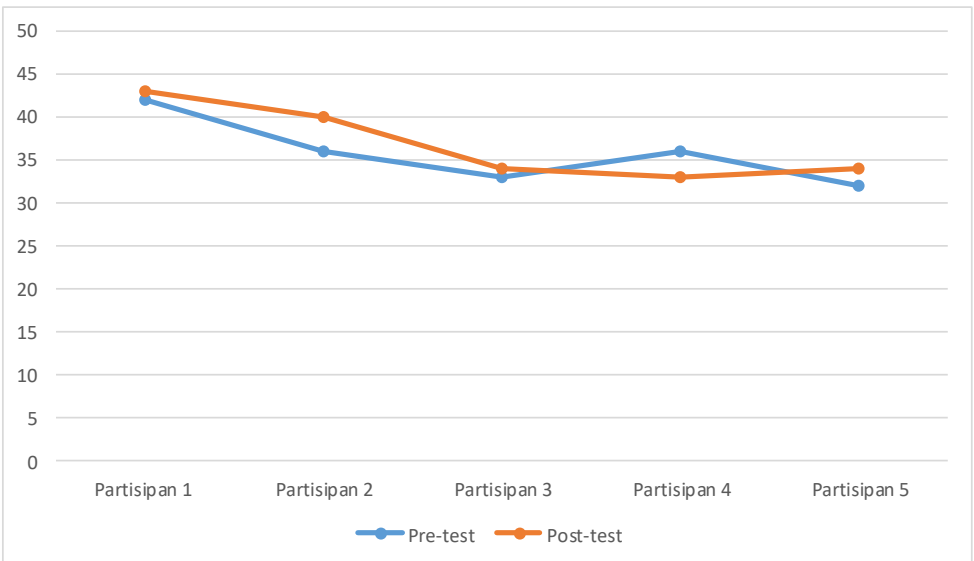

Grafik 1. Perbandingan pre-test dan post-test kuesioner kontrol diri.



Gambar 1. Hasil Karya sesi 3 (sesi berkelompok)

Sumber Gambar: dokumentasi peneliti 


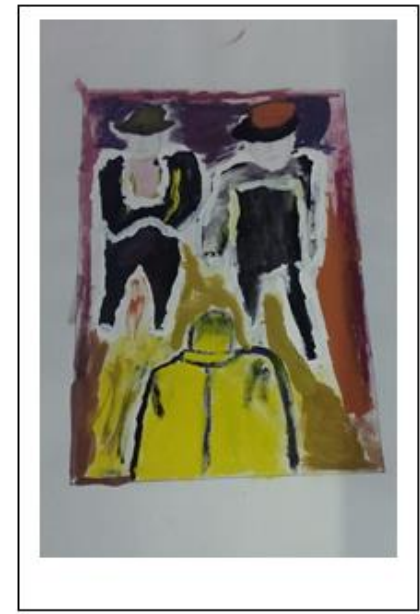

Gambar 1. Hasil Karya sesi 7 (sesi berkelompok)

Sumber Gambar: dokumentasi peneliti

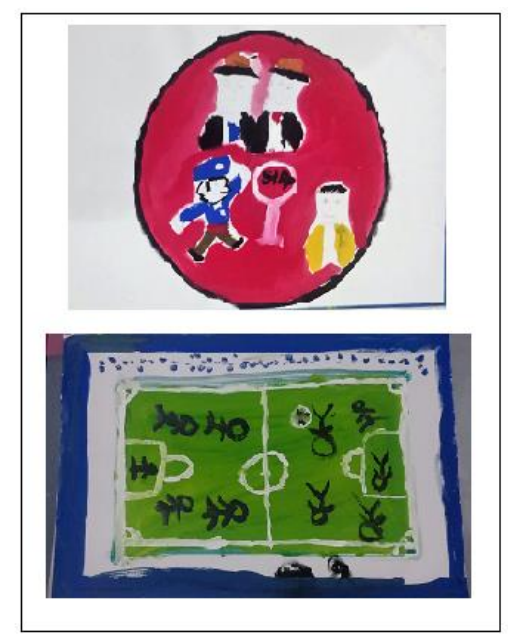

Gambar 1. Hasil Karya sesi 8 (sesi berkelompok), gambar atas merupakan gambar atas instruksi peneliti, gambar bawah merupakan gambar yang digambar secara bebas oleh para partisipan.

Sumber Gambar: dokumentasi peneliti

\section{KESIMPULAN DAN SARAN}

Intervensi kelompok ini ditujukan untuk meningkatkan kontrol diri pada anak didik lapas yang menunjukan perilaku bermasalah di dalam instansi LPKA Salemba dengan menerapkan art therapy. Hasil dari penilaian tes menggambar orang dan menggambar pohon menunjukan bahwa terdapat perubahan pada kontrol diri anak didik lapas yang mendapatkan art therapy. Tes menggambar atau grafis diukur melalui kesan gambar, kualitas coretan, makna gambar, dan pengisian ruang (Sumitardja, 2016). Adanya perubahan kesan gambar, penggunaan ruang, kualitas garis, dan coretan yang dihasikan oleh para partisipan menunjukan lebih adanya kontrol diri yang terarah. Hal ini didukung dengan hasil dari kuesioner brief self-control scale yang menunjukan 4 dari 5 partisipan menunjukan peningkatan skor pada saat post-test. Berdasarkan hasil tersebut dapat ditarik kesimpulan bahwa penerapan art therapy pada anak didik lapas yang memiliki perilaku bermasalah di dalam instasi LPKA tergolong berhasil dalam meningkatkan kontrol diri. 


\section{Saran untuk peneliti selanjutnya.}

Berikut merupakan beberapa saran yang dapat dipertimbangkan oleh peneliti selanjutnya. Peneliti selanjutnya diharapkan dapat memperkaya sumber referensi mengenai kontrol diri dan penanganan dengan menggunakan art therapy lebih dalam. Untuk mendapatkan hasil yang lebih signifikan, peneliti selanjutnya disarankan untuk merancang sesi yang lebih panjang. Peneliti selanjutnya disarankan untuk menguji validitas dan reliabilitas alat ukur pada populasi yang serupa dengan partisipan. Studi pada lembaga dan sampel yang serupa disarankan untuk memperkaya penelitian.

\section{Ucapan Terima Kasih (Acknowledgement)}

Ucapan terima kasih diberikan kepada partisipan yang bersedia untuk mengikuti seluruh proses penelitian, kepada lembaga-lembaga terkait yang memberikan izin untuk terlaksananya penelitian dan kepada pihak-pihak yang telah membantu terlaksananya penelitian.

\section{REFERENSI}

Blackhart, Ginnet C., Nelson, Brian C., Winter, A., Rockney, A. (2011). Self-control in relation ti feeling of belonging and acceptance. Psychology Press: Self and Identity, 10, 152-165. http://www.psypress.com/sai.

DeWall, C.N., Finkel, N.J., \& Denson, T.F. (2011). Self-control inhibits aggression. Social and Personality Psychology Compass, 458-472. Diunduh dari http://faculty.wcas.northwestern.edu/elifinkel/documents/64_DeWallFinkelDenson2011_S PPCpdf

Friese, M., Hofmann, W. (2009). Control me or I will control you: Impulses, trait self-control and guidance of behavior. Journal of Research in Personality, 43, 795-805.

Gunawan, Lidya N. (2017). Hubungan antara kontrol diri dan penyesuaian diri dengan kedisiplinan siswa MTs Sulaiman Yasin Samarinda. PSIKOBORNEO, 2017, 5(1): 104-117.

Huss, E., Sarid, O., Cwikel, J. (2010). Using art as a self-regulation tool in war situation: A model for a social worker. Journal of Health and Social Worker, 35(3), 201-209.

Koiv, K., Kaudne, L. (2015). Impact of integrated art therapy: An Intervention program for young female offender in correctional institution. Scientific Research Publishing. Diakses dari http://file.scirp.org/Html/1-6901356_53112.htm.

Mahardika, B. (2017). Implementasi metode art therapy dalam mencerdaskan emosional siswa. Jurnal Kependidikan UTILE. Volume 3(2). Diakses dari http://jurnal.ummi.ac.id/index.php/JUT/article/view/68.

Muraven, M., Baumeister, Roy F. (2000). Self-regulation and depletion of limited resources: Does self-control resemble muscle. Psychological bulletin, 126(2), 247-259.

Necka, E. (2015). Self-control scale AS-36: Contruction and validation study. Polish Psychological Bulletin, 46 (3), 488-497.

Nurfaujiyanti \& Suryadi, B. (2010). Hubungan pengendalian diri (self-control) dengan agresivitas anak jalanan. [Skripsi, UIN Syarif Hidayatullah]. Diakses dari http://repository.uinjkt.ac.id/dspace/handle/123456789/949

Rubin, J. A. (2005). Child art therapy. New Jersey: John Willey \& Sons.

Smeijsters, H., Kil, J., Kurstjens, H., Welten, J., Willemars, G. (2010). Art therapy for young offender in secure case -A practice-base research. The Art in Psychotherapy, http://dx.doi.org/10.1016/j.aip.2010.10.005. 
Taghva, N. \& Nezhadi, F. (2010). Using Art therapy methods to investigate aggression and revenge in children. Diakses dari http://www.inter-disciplinary.net/wpcontent/uploads/2010/06/Taghva-Paper.pdf

Tangney, June. P, Baumeister, Roy. F, Boone, Angie. L. (2004). High Self-Control Predicts Good Adjustment, Less Pathology, Better Grades, and Interpersonal Success. Blackwell: Journal of Personality 72; 2

Turipno, R. E. (2012). Akhlak remaja kian parah. kompasiana.com. Diakses dari http://www.kompasiana.com/rioturipno/akhlak-remaja-kian-

parah_550d9e86813311bf36b1e4ac 